\title{
Seasonal variability of near-surface zooplankton community structure in the southern Gulf of Mexico
}

\author{
Leonardo Cruz-Rosado $^{1}$, Wilfrido M. Contreras-Sánchez ${ }^{1}$, Ulises Hernández-Vidal ${ }^{1}$ \\ Jaime Gómez-Gutiérrez ${ }^{2}$, María de Jesús Contreras-García ${ }^{1}$ \& Alejandro Mcdonal-Vera ${ }^{1}$ \\ ${ }^{1}$ División Académica de Ciencias Biológicas, Universidad Juárez Autónoma de Tabasco \\ Villahermosa, Tabasco, México \\ ${ }^{2}$ Departamento de Plancton y Ecología Marina, Centro Interdisciplinario de Ciencias Marinas \\ Instituto Politécnico Nacional, La Paz, Baja California Sur, México \\ Corresponding author: Wilfrido M. Contreras-Sánchez (contrerw@hotmail.com)
}

\begin{abstract}
The zooplankton taxonomic group composition was analyzed in a known spawning area for snooks of the family Centropomidae during March 2011-February 2012 near the González River's mouth, a tributary of the Grijalva-Usumacinta River system, discharging into the southern Gulf of Mexico. Zooplankton was collected near the surface using three distinct zooplankton nets $(20,64$, and $120 \mu \mathrm{m})$. Sixteen zooplankton taxonomic groups were collected between the three nets. Copepoda (76.9\%), Trematoda (6.7\%), Bivalvia (4.6\%), and Chaetognatha (Sagittoidea 4.3\%) numerically dominated zooplankton community structure. The 120 and $64 \mu \mathrm{m}$ nets collected the highest diversity of zooplankton (15 taxa). Zooplankton was more abundant during June-October (summer storm season). They associated with lower salinities (due to the increase in the discharge volume of the Grijalva-Usumacinta River system) and higher regional primary productivity than observed during the rest of the year (March-May, dry season, and November-February, winter storm season). The highest peak of zooplankton abundance was found in November during the beginning of winter storms. Nine taxonomic groups were observed frequently and abundantly during the summer storm season, while only five taxonomic groups were abundant during the dry season.
\end{abstract}

Keywords: zooplankton; taxonomic groups; abundance; distribution; seasonal variability; Gulf of Mexico

\section{INTRODUCTION}

Planktonic organisms constitute the base for most trophic connections in marine ecosystems. Space-time availability of zooplankton is essential for the survival of fish larvae that prey on them during the critical period of early development after depleting their yolk sac and when exogenous food must be ingested before reach the period-of-no-return (Yúfera \& Darias, 2007). Zooplankton productivity and biomass strongly influence fish population recruitment and frequently delimit the reproductive periods and species reproductive behavior, including species targeted for regional fishery activities (Conde-Porcuna et al., 2004; Álvarez-Fernández et al., 2015; Jackson \& Lenz, 2016). Several fish species tend to synchronize their reproductive spawning events with periods with high zooplankton abundance because fish larvae prey on dino- flagellates, invertebrate eggs, and copepods (Phelps et al., 2005; Álvarez-Fernández et al., 2015) promoting high survival of fish larvae (Alvariño, 1980; Sherman et al., 1984). Fish larvae of several marine species prefer to prey on small zooplankton because of their small mouth size and limited swimming capabilities (Purcell \& Grover, 1990; Støttrup, 2006; Puello-Cruz et al., 2008).

The Mississippi and the Grijalva-Usumacinta rivers are the main freshwater discharges on the Gulf of Mexico. Other minor contributions are San Pedro, San Pablo, and Coatzacoalcos rivers. All these rivers significantly influence the ecological dynamics of the coastal habitats (Monreal-Gomez \& Salas-de León, 2004). The river plumes promote higher primary production that contributes to the sustainment of costeffective fisheries within the region (Botello et al., 2005). Significant river plume nutrient-inputs in the

Corresponding editor: Sergio Palma 
Gulf of Mexico occur during the rainy season (JuneOctober) increasing, with some lag, zooplankton abundance (Contreras-Espinoza, 2016). This seasonal nourishment process coincides with the vast abundance of fish larvae along the littoral zone of the Gulf of Mexico (Hopkins, 1982; Ortner et al., 1989; FloresCoto et al., 2009).

In the southern Gulf of Mexico sub-region, the Usumacinta-Grijalva River system has water discharges between 3000 and $4400 \mathrm{~m}^{3} \mathrm{~s}^{-1}$ (YáñezArancibia \& Day, 2004). This freshwater discharge provides a large load of sediments and nutrients to the southern region of the Gulf of Mexico, particularly during the discharge peaks (September-October) (West et al., 1985). The high nutrient availability could promote massive planktonic blooms that represent available prey for fish larvae and juveniles. However, the taxonomic group composition and seasonal patterns of the zooplanktonic community in the southern Gulf of Mexico have not been studied yet. We investigated the fluctuations of the major zooplankton taxonomic groups collected near the González River mouth -a distributary of the Grijalva-Usumacinta River systemthat is an area considered by the local anglers as a snook spawning ground. We investigate the surface sea layer because regionally, food particles exist in high concentrations, making it the most productive stratum in the epipelagic ecosystem, where most of the trophic interactions (Espinosa-Fuentes et al., 2009).

\section{MATERIALS AND METHODS}

Monthly zooplankton samplings were collected from March 2011 to February 2012 near the influence of the González River, as part of the Grijalva-Usumacinta River system. Zooplankton was collected near the surface (2-3 $\mathrm{m}$ depth) from three sites in a spawning ground identified by local anglers and reported for two snook species: Centropomus undecimalis and Centropomus parallelus (Hernández-Vidal et al., 2014). These three sampling sites were located at: site A, $18^{\circ} 26^{\prime} 4.10^{\prime \prime} \mathrm{N}, 92^{\circ} 59^{\prime} 47.60^{\prime \prime} \mathrm{W}$ (7-8 m depth); site B, $18^{\circ} 26^{\prime} 59.16^{\prime \prime} \mathrm{N}, 92^{\circ} 59^{\prime} 59.51^{\prime \prime} \mathrm{W}$ (7.5-9 m depth); and site $\mathrm{C}, 18^{\circ} 27^{\prime} 30.71 " \mathrm{~N}, 93^{\circ} 00^{\prime} 5.94^{\prime \prime} \mathrm{W}$ (8-10 m depth) (Fig. 1). Further statistical analysis showed no significant differences in zooplankton abundance and taxonomic group composition among sampling sites; therefore, each sampling station was considered as replicate for the entire sampled area.

\section{Environmental variables and zooplankton sampling}

Seawater was collected between 1-2 $\mathrm{m}$ depth using a Vann Dorn bottle (WildCo, USA) at each sampling site to measure sea surface temperature $\left({ }^{\circ} \mathrm{C}\right)$, salinity, and dissolved oxygen concentration ( $\left.\mathrm{mg} \mathrm{O}_{2} \mathrm{~L}^{-1}\right)$. Temperature and $\mathrm{DO}$ were measured using a calibrated multisensor (YSI 55 ${ }^{\mathrm{TM}}$, Yellow Springs, OH, USA). Salinity $( \pm 1.0)$ was measured with a Bio-Marine Inc. Aquafauna $^{\mathrm{TM}}$ refractometer (Hawthorne, CA, USA). Sea surface chlorophyll- $a\left(\mathrm{mg} \mathrm{Chl}-a \mathrm{~m}^{-3}\right)$ was obtained from MODIS-Aqua NASA satellite images (five-day averages), sea surface temperature $\left(\mathrm{SST},{ }^{\circ} \mathrm{C}\right)$ data were obtained from MODIS-Terra-MODIS-Aqua satellite website (https://podaac.jpl.nasa.gov/dataaccess). Monthly rainfall $\left(\mathrm{mm} \mathrm{month}{ }^{-1}\right)$ was obtained from the Comisión Nacional del Agua (México) (CONAGUA) (https://sih.conagua.gob.mx/) station $\mathrm{N}^{\circ} 27034$ located $22 \mathrm{~km}$ southwest from the present area of study $\left(18^{\circ} 23^{\prime} 44.00^{\prime \prime} \mathrm{N}, \quad 93^{\circ} 12^{\prime} 43.99^{\prime \prime} \mathrm{W}\right)$. The southern subregion of the Gulf of Mexico has three climatic seasons: dry, summer storms, and winter storms (Yáñez-Arancibia \& Day, 2004). During the dry season (DS: March-May), SE winds prevail, with a mean air temperature of $28.1^{\circ} \mathrm{C}$ and mean rainfall of $164.8 \mathrm{~mm}$ month $^{-1}$. During the summer storm season (SSS: JuneOctober), SE winds still prevail, and there is a similar mean air temperature of $28.3^{\circ} \mathrm{C}$, but mean rainfall increases almost five times $\left(976.7 \mathrm{~mm}\right.$ month $\left.^{-1}\right)$. During the winter storm season (WSS: NovemberFebruary), north winds frequently occur (regionally known as "nortes" in Spanish) with an average air temperature of $24.4^{\circ} \mathrm{C}$ and mean precipitation of 345.6 $\mathrm{mm}$ month $^{-1}$ (Ayala-Pérez et al., 2012). The analysis of the last five years (2015-2019) Chl- $a$ data obtained by the MODIS-Aqua NASA satellite indicate that the highest mean values correspond to the WSS (3.52) with a very distinctive peak during November (4.00) compared to mean values from the DS (2.56) and the SSS (2.73) coinciding with information reported at the nearby Terminos Lagoon by Yáñez-Arancibia \& Day (2004), and Herrera-Silveira et al. (2019).

Zooplankton was collected during daytime every month using three simple, conical plankton nets, each one with a diameter of $30 \mathrm{~cm}$ and a length of $60 \mathrm{~cm}$, but distinct mesh sizes: 20, 64, and $120 \mu \mathrm{m}$. Nets were towed near the surface for $5 \mathrm{~min}$ while the boat was underway at $2.5 \mathrm{~km} \mathrm{~h}^{-1}$. Plankton samples were preserved in $4 \%$ buffered formalin. A total of 108 zooplankton samples were collected from March 2011 to February 2012. Zooplankton abundance was standardized to the number of individuals per $100 \mathrm{~m}^{3}$ (ind $100 \mathrm{~m}^{-3}$ ). The identification of each zooplankton species in a diverse zooplankton community is complicated and time-consuming. Therefore, zooplankton was here identified to taxonomic levels, higher than suborder to evaluate zooplankton seasonal changes through an annual cycle using four zooplankton taxonomic keys (Smith, 1977; Boltovskoy, 1981; Báez, 1997; 


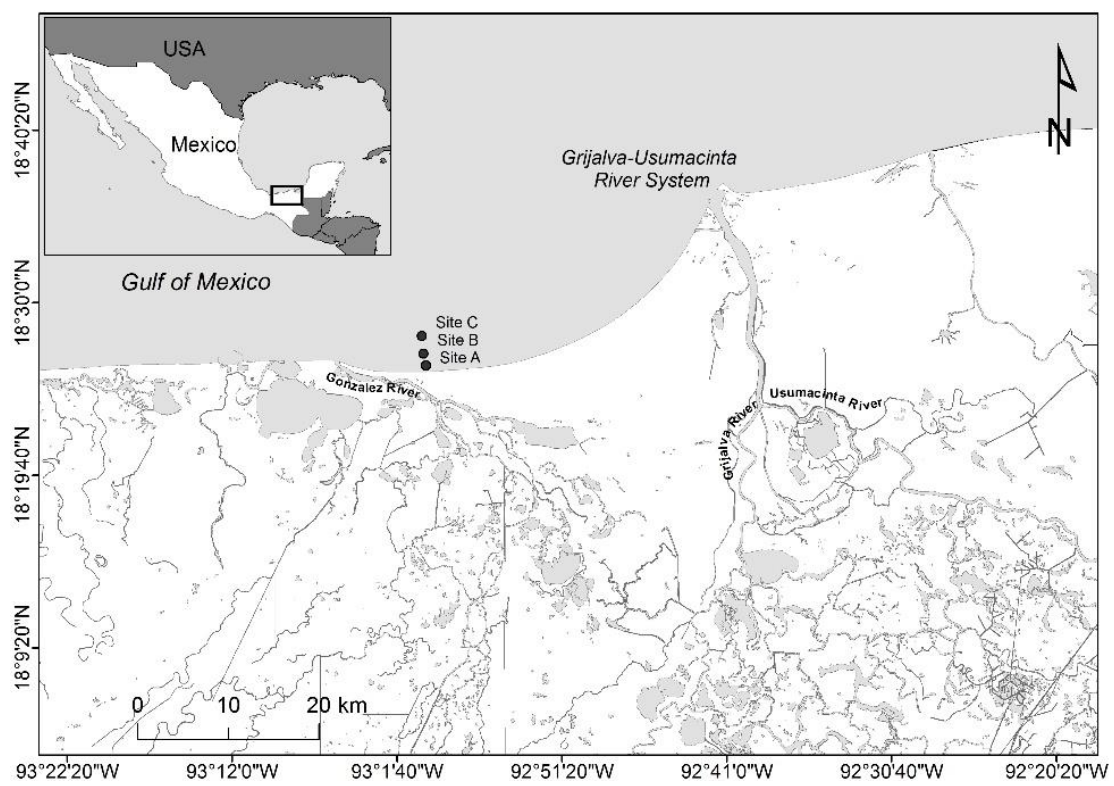

Figure 1. Study area showing the location of the three sampling sites, known by local anglers as snook spawning sites over the continental shelf of Tabasco, Mexico.

Perry, 2003). The names utilized for these taxa follow the World Register of Marine Species (WoRMS, 2019) database (http://www.marinespecies.org/). Three different groups were identified based on their frequency of the capture of each zooplankton taxonomic group: high (>9 months), moderate (5-8 months), and low (<4 months) frequency of appearance.

\section{Data analysis}

The statistical significance of differences between the community taxonomic composition and abundance of zooplankton among the three climatic seasons and the three mesh sizes was evaluated using Multi-Response Permutation Procedure (MRPP). The MRPP is a nonparametric multivariate procedure for testing the hypothesis that there are no differences between $a$ priori classified group (McCune \& Mefford, 2011). The Sorensen (Bray-Curtis) distance measure was chosen in the MRPP analyses because it retains sensitivity in heterogeneous data sets and gives less weight to outlier abundance values.

A canonical correspondence analysis (CCA) was conducted to infer how the zooplankton community structure was associated with the multi-dimensional gradients of the five environmental variables: sea surface temperature, salinity, satellite sea surface chlorophyll- $a$ concentration, dissolved oxygen concentration, and monthly rainfall. Zooplankton abundance was $\log (x+1)$ transformed to linearize the species matrix, and data of the five environmental variables were transformed to generalized relativization per column to give the five variables comparable weight (Ter Braak \& Verdonschot, 1995; McCune \& Mefford, 2011). Data matrices were organized using the Excel software, and statistical data analyses were performed using PC-ORD Multivariate Analysis of Ecological Data v.6.0 software (MjM Software design) (McCune $\&$ Mefford, 2011). Graphic representation of the data was done using the software SigmaPlot ${ }^{\circledR}$ v14.

\section{RESULTS}

\section{Environmental conditions}

Sea surface temperature varied from $24.4^{\circ} \mathrm{C}$ in March to $28.7^{\circ} \mathrm{C}$ in September with the highest mean value obtained during the SSS $\left(27.75 \pm 1.01^{\circ} \mathrm{C}\right)$. The lowest mean values were recorded during the DS. Salinity varied from 30.22 in September to 34.45 in July with the highest mean during the SSS $(32.63 \pm 2.35)$. Dissolved oxygen concentration was higher during the WSS with a mean value of $8.01 \pm 1.27 \mathrm{mg} \mathrm{O}_{2} \mathrm{~L}^{-1}$, with a range of $4.75 \mathrm{mg} \mathrm{O}_{2} \mathrm{~L}^{-1}$ in July and $8.68 \mathrm{mg} \mathrm{O}_{2} \mathrm{~L}^{-1}$ in February (Table 1 ). Monthly cumulative rainfall was zero in April, and the highest rainfall was $468.20 \mathrm{~mm}$ month $^{-1}$ in October. Mean cumulative rainfall was fivefold higher during the summer storms season (206.30 \pm $146.20 \mathrm{~mm} \mathrm{month}^{-1}$ ) than during the other two seasons. Satellite sea surface Chl- $a$ concentration ranged from $0.75 \mathrm{mg}$ Chl $-a \mathrm{~m}^{-3}$ in February to $5.17 \mathrm{mg}$ Chl $-a \mathrm{~m}^{-3}$ in September being slightly higher during WSS (3.24 \pm $2.26 \mathrm{mg} \mathrm{Chl}-a \mathrm{~m}^{-3}$ ) than during the other two seasons. 
Table 1. Mean \pm standard deviation of environmental variables recorded in situ at the time of sampling in the three sampling sites (DO: dissolved oxygen, SST: sea surface temperature and salinity; $\mathrm{n}=3$ ), monthly average values of and satellite chlorophyll- $a$ concentration ( $\mathrm{n}=29-31 \mathrm{~d})$ and monthly cumulative rainfall recorded during March 2011-February 2012 at the continental shelf of Tabasco, Mexico. DS: dry season; SSS: summer storm season, WSS: winter storm season.

\begin{tabular}{llccccc}
\hline Season & Month & $\begin{array}{c}\text { SST } \\
\left({ }^{\circ} \mathrm{C}\right)\end{array}$ & Salinity & $\begin{array}{c}\text { DO } \\
\left(\mathrm{mg} \mathrm{O}_{2} \mathrm{~L}^{-1}\right)\end{array}$ & $\begin{array}{c}\text { Rainfall } \\
\left(\mathrm{mm} \mathrm{month}^{-1}\right)\end{array}$ & $\begin{array}{c}\text { Chlorophyll }-a \\
\left(\mathrm{mg} \mathrm{Chl}-a \mathrm{~L}^{-1}\right)\end{array}$ \\
\hline \multirow{3}{*}{ DS } & Mar & $24.43 \pm 0.30$ & $32.22 \pm 1.30$ & $8.30 \pm 0.82$ & $60.43 \pm 0.00$ & $3.00 \pm 0.31$ \\
& Apr & $26.24 \pm 1.08$ & $32.00 \pm 1.73$ & $6.52 \pm 0.80$ & $0.00 \pm 0.00$ & $3.30 \pm 0.20$ \\
& May & $26.48 \pm 0.79$ & $31.66 \pm 1.32$ & $7.32 \pm 0.43$ & $34.02 \pm 0.00$ & $2.62 \pm 0.74$ \\
\hdashline & Jun & $27.95 \pm 0.49$ & $33.44 \pm 1.94$ & $6.09 \pm 0.07$ & $70.68 \pm 0.00$ & $2.57 \pm 0.57$ \\
\multirow{3}{*}{ SSS } & Jul & $27.62 \pm 1.02$ & $34.44 \pm 1.67$ & $4.75 \pm 0.93$ & $188.21 \pm 0.00$ & $2.00 \pm 0.70$ \\
& Aug & $26.77 \pm 1.12$ & $33.29 \pm 2.50$ & $7.56 \pm 0.55$ & $62.03 \pm 0.00$ & $2.14 \pm 0.07$ \\
& Sep & $28.72 \pm 0.35$ & $30.22 \pm 1.86$ & $6.42 \pm 1.00$ & $316.84 \pm 0.00$ & $5.17 \pm 4.42$ \\
& Oct & $27.67 \pm 0.78$ & $31.78 \pm 1.45$ & $5.57 \pm 1.01$ & $468.23 \pm 3.80$ & $4.17 \pm 1.78$ \\
$-\cdots$ & Nov & $27.18 \pm 0.70$ & $32.33 \pm 1.00$ & $6.93 \pm 0.98$ & $131.88 \pm 0.00$ & $5.03 \pm 2.76$ \\
WSS & Dec & $25.94 \pm 1.42$ & $34.11 \pm 1.62$ & $8.10 \pm 1.70$ & $67.85 \pm 0.00$ & $3.99 \pm 1.10$ \\
& Jan & $25.12 \pm 1.12$ & $32.44 \pm 0.88$ & $8.31 \pm 1.07$ & $127.89 \pm 0.07$ & $3.18 \pm 0.29$ \\
& Feb & $25.30 \pm 0.30$ & $31.31 \pm 0.96$ & $8.68 \pm 0.33$ & $192.57 \pm 1.13$ & $0.75 \pm 1.49$ \\
\hline Annual & Range & $24.43-28.72$ & $30.22-34.44$ & $4.75-8.68$ & $00.00-468.20$ & $0.75-5.17$ \\
mean & Mean & $26.83 \pm 1.28$ & $32.35 \pm 1.17$ & $6.93 \pm 1.22$ & $143.38 \pm 133.96$ & $3.13 \pm 1.28$ \\
\hline \multirow{2}{*}{ Seasonal } & DS & $25.71 \pm 1.20$ & $31.96 \pm 1.43$ & $7.38 \pm 1.02$ & $31.47 \pm 25.19$ & $2.97 \pm 0.54$ \\
mean & SSS & $27.75 \pm 1.01$ & $32.63 \pm 2.35$ & $6.08 \pm 1.21$ & $206.30 \pm 146.20$ & $3.21 \pm 2.42$ \\
& WSS & $25.89 \pm 1.24$ & $32.55 \pm 1.49$ & $8.01 \pm 1.27$ & $39.41 \pm 20.46$ & $3.24 \pm 2.26$ \\
\hline
\end{tabular}

Higher rainfall occurred from September to November, coinciding with high concentrations of sea surface Chl$a$ and high values of SST (Table 1).

\section{Identified zooplankton taxonomic groups}

Sixteen zooplankton taxonomic groups were identified from the 108 zooplankton samples collected between March 2011 and February 2012 (Table 2). Zooplankton included nine classes (Actinopterygii, Appendicularia, Bivalvia, Echinodermata, Euphausiacea, Hydrozoa, Insecta, Sagittoidea, and Trematoda) one subclass (Copepoda), four orders (Amphipoda, Decapoda, Gastropoda, and Stomatopoda), and two suborders (Cladocera and Polychaeta) with clearly distinct morphological and life strategy zooplankton taxonomic groups. Fish eggs and larvae abundance were combined as ichthyoplankton (Class Actinopterygii) for statistical analyses.

\section{Annual relative abundance for all three types of mesh size}

Out of the 16 zooplankton taxonomic groups, 15 were collected with the $120 \mu \mathrm{m}$, and $64 \mu \mathrm{m}$ plankton mesh size nets and only 13 taxa with the $20 \mu \mathrm{m}$ mesh size net; this difference is caused by the absence of Stomatopoda, Hydrozoa, and Amphipoda in the latter. Ichthyoplankton was absent from the $64 \mu \mathrm{m}$ net and Amphipoda from the $120 \mu \mathrm{m}$ net. Copepods dominated the relative monthly abundance in all the zooplankton sampling nets (73.7-79.8\%) (Table 2, Fig. 2). The taxonomic groups that followed copepods in abundance for all nets were Trematoda (4.2-9.1\%), Bivalvia (2.5$6.2 \%)$, Sagittoidea (3.8-5.14\%); however, their relative abundances were much smaller than copepods. Ichthyoplankton was captured with the 120 and $20 \mu \mathrm{m}$ nets (Table 2). The rest of the taxonomic groups collected typically summed $<2 \%$ in each net (Table 2 , Fig. 2).

\section{Seasonal variation in zooplankton taxonomic composition}

The identification of zooplankton taxonomic groups, based on their frequency of appearance, indicated that Copepoda, Decapoda, Sagittoidea, and Trematoda were highly frequent. Bivalvia, Cladocera, and Polychaeta were moderately frequent, and Appendicularia, Amphipoda, Echinodermata, Euphausiacea, Gastropoda, Hydrozoa, Ichthyoplankton, Insecta, and Stomatopoda showed low frequency of appearance (Table 2).

Combining zooplankton abundance of the three sampling sites and the three mesh sizes showed zooplankton abundances had the maximum abundance during November $(303.21 \pm 152.76$ thousands of individuals per $100 \mathrm{~m}^{3}$; median \pm interquartile range). The lowest abundances were observed during February (53.70 \pm 116.95$)$ and March (48.46 \pm 22.92$)$ (Fig. 3). 
Table 2. Annual mean \pm standard deviation of zooplankton abundance (thousands of individuals per $100 \mathrm{~m}^{-3}$ ), relative abundance (\%), and frequency of appearance (shown between parentheses) for each zooplankton taxonomic group collected over the continental shelf of Tabasco (three sampling locations combined) collected between March 2011-February 2012 with three different zooplankton net mesh sizes (20, 64, and $120 \mu \mathrm{m})$. Actinopterygii (includes fish eggs and larvae).

\begin{tabular}{|c|c|c|c|c|c|c|}
\hline \multirow{2}{*}{ Taxonomic groups } & \multicolumn{3}{|c|}{ Zooplankton net mesh size $(\mu \mathrm{m})$} & \multicolumn{3}{|c|}{ Relative abundance (frequency) } \\
\hline & 20 & 64 & 120 & 20 & 64 & 120 \\
\hline Copepoda & $57.14 \pm 46.68$ & $127.64 \pm 93.41$ & $114.57 \pm 81.37$ & $77.33(12)$ & $79.83(12)$ & $73.70(12)$ \\
\hline Trematoda & $6.72 \pm 7.06$ & $6.77 \pm 8.78$ & $10.45 \pm 17.04$ & $9.09(9)$ & $4.23(8)$ & $6.72(9)$ \\
\hline Bivalvia & $1.85 \pm 1.74$ & $8.01 \pm 16.2$ & $9.63 \pm 11.52$ & $2.50(8)$ & $5.01(8)$ & $6.20(7)$ \\
\hline Sagittoidea & $3.80 \pm 6.36$ & $5.99 \pm 7.62$ & $6.01 \pm 5.74$ & $5.14(8)$ & $3.75(11)$ & $3.87(10)$ \\
\hline Decapoda & $0.53 \pm 0.76$ & $4.64 \pm 9.20$ & $5.87 \pm 15.10$ & $0.72(6)$ & $2.90(11)$ & $3.77(10)$ \\
\hline Echinodermata & $0.16 \pm 0.57$ & $1.13 \pm 3.45$ & $5.31 \pm 15.70$ & $0.22(1)$ & $0.71(3)$ & $3.41(3)$ \\
\hline Polychaeta & $1.01 \pm 1.68$ & $1.27 \pm 3.94$ & $2.10 \pm 3.43$ & $1.36(6)$ & $0.80(5)$ & $1.35(5)$ \\
\hline Cladocera & $2.18 \pm 5.67$ & $2.87 \pm 6.88$ & $0.73 \pm 1.86$ & $2.95(3)$ & $1.80(3)$ & $0.47(5)$ \\
\hline Appendicularia & $0.09 \pm 0.15$ & $1.07 \pm 2.62$ & $0.35 \pm 0.81$ & $0.13(4)$ & $0.67(4)$ & $0.22(3)$ \\
\hline Stoma & $0.00 \pm 0.00$ & $0.07 \pm 0.25$ & $0.16 \pm 0.50$ & $0.00(0)$ & $0.05(1)$ & $0.11(2)$ \\
\hline Hydrozoa & $0.00 \pm 0.00$ & $0.04 \pm 0.08$ & $0.10 \pm 0.21$ & $0.00(0)$ & $0.02(2)$ & $0.07(3)$ \\
\hline Euphausiacea & $0.15 \pm 0.39$ & $0.04 \pm 0.13$ & $0.07 \pm 0.19$ & $0.20(2)$ & $0.02(1)$ & $0.05(2)$ \\
\hline Actinopterygii & $0.04 \pm 0.08$ & $0.00 \pm 0.00$ & $0.05 \pm 0.14$ & $0.02(2)$ & $0.00(0)$ & $0.02(2)$ \\
\hline Insecta & $0.01 \pm 0.03$ & $0.02 \pm 0.06$ & $0.04 \pm 0.13$ & $0.01(1)$ & $0.01(2)$ & $0.02(1)$ \\
\hline Gastropoda & $0.22 \pm 0.50$ & $0.05 \pm 0.14$ & $0.02 \pm 0.06$ & $0.30(3)$ & $0.03(2)$ & $0.01(1)$ \\
\hline Amphipoda & $0.00 \pm 0.00$ & $0.27 \pm 0.88$ & $0.00 \pm 0.00$ & $0.00(0)$ & $0.17(2)$ & $0.00(0)$ \\
\hline
\end{tabular}

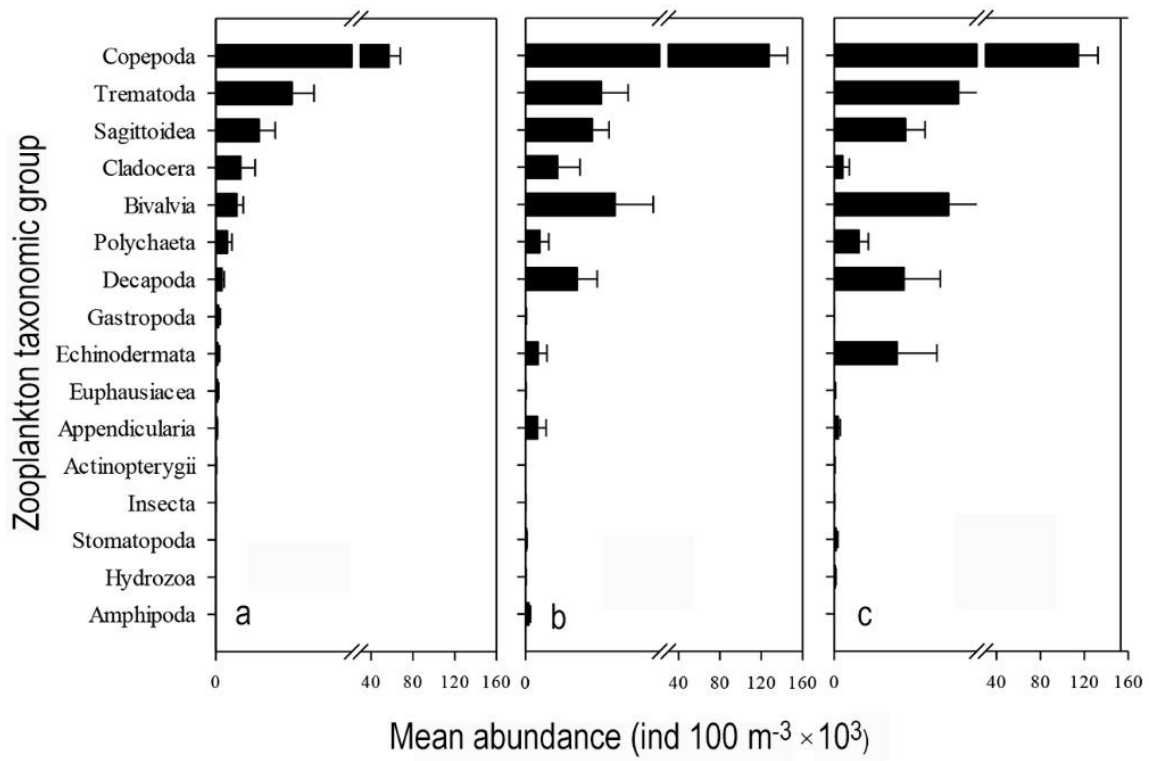

Figure 2. Average standardized ( \pm SE, standard error) abundance expressed in thousands of individuals per $100 \mathrm{~m}^{3}$ for each zooplankton taxonomic group $(\mathrm{n}=36)$ captured with each type of zooplankton net: a) 20, b) 64 , and c) $120 \mu \mathrm{m}$. Axis break in figures omits data between $12-30$ ind $100 \mathrm{~m}^{-3}$.

During May and September, high values were also observed $(216.11 \pm 171.58$ and $183.37 \pm 250.16$, respectively).

The analysis of the zooplankton abundance showed higher SSS abundance during WSS storms season than during DS and WSS? (these two with similar magnitude of zooplankton abundance) (Fig. 4a).
Copepod abundance accounted for $>70 \%$, mostly driving monthly total zooplankton abundance patterns throughout the year (Fig. 4b). Nine taxonomic groups were observed frequently and abundantly during summer, while only five zooplankton taxonomic groups were abundant during DS. Bivalvia, Cladocera, Sagittoidea, and Trematoda abundance showed a similar seasonal 


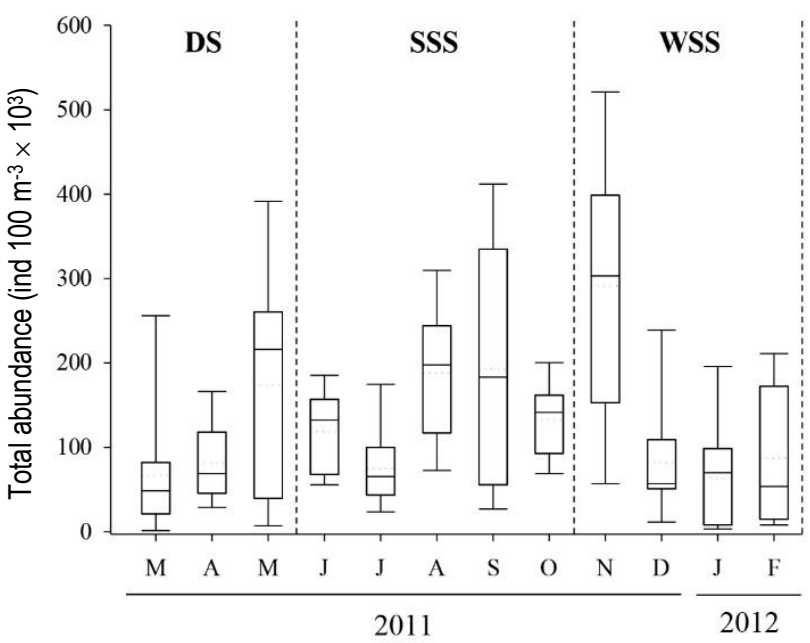

Figure 3. Whisker box plots of monthly standardized total zooplankton abundance (all groups combined) expressed in thousands of individuals per $100 \mathrm{~m}^{3}$. Each value in the boxes is the sum of all taxonomic groups captured in three sites with three net sizes $(n=9)$. Dotted lines inside the boxes show mean values, while solid lines represent the medians. Climatic seasons are separated by shaded lines. DS: dry season; SSS: summer storms season; WSS: winter storms season. The year of the sampling is stated underneath the sampled month.

trend throughout the year (Figs. 4c-f). In contrast, Decapoda and Polychaeta were more abundant during the DS than during the rest of the year (Figs. 4g-h). During summer and the beginning of WSS (JulyNovember), the higher values for SST, salinity, and rainfall coincided with zooplankton abundance high values. The highest abundance of zooplankton that occurred during November was preceded by two months of high sea surface Chl- $a$ concentrations, which progressively decreased in December.

\section{Zooplankton community assemblage}

Zooplankton abundance and community taxonomic structure showed statistically significant differences among the three climatic seasons (MRPP analysis, $\mathrm{A}=$ $0.018, P<0.05)$. Zooplankton abundance was significantly higher during the SSS than during DS ( $P$ $=0.04)$ and WSS $(P=0.001)$. However, zooplankton abundance was not significantly different between DS and WSS (MRPP; $P=0.50$ ). Zooplankton had significant differences in abundance among taxonomic groups from samples collected using different plankton mesh net sizes (MRPP; A $=0.02, P=0.04$ ). The smaller zooplankton (captured in the $20 \mu \mathrm{m}$ mesh size) was significantly less abundant (by several orders of magnitude) and diverse than zooplankton samples collected with the other two plankton net mesh sizes (64 $\mu \mathrm{m} P<0.001$ and $120 \mu \mathrm{m} P=0.004)$. Zooplankton groups collected with the 64 and $120 \mu \mathrm{m}$ mesh size nets were practically identical (MRPP, $P=0.99$ ). Zooplankton community structure and abundance showed no significant statistical differences among the three sampling sites located close to each other over the continental shelf (MRPP; $\mathrm{A}=0.005, P>0.2$ ).

The results from CCA ordination of zooplankton groups and environmental parameters indicated that the surveyed environmental parameters might play a minor role in the zooplankton assemblage, only explaining $6.0 \%$ of the total variance. The zooplanktonic abundance observed during the climatic seasons, indicated in the CCA biplot, shows that during the SSS, abundances have strong associations with rainfall and SST. Abundances during WSS and the DS were strongly correlated to high values of DO, and lowerthan-average temperature and precipitation (Table 3, Fig. 5a). The seasonal effects of the variables incorporated in the second axis mainly consisted of a strong positive association with Chl- $a$ (Table 3, Fig. 5). In terms of zooplanktonic groups, Appendicularia and Bivalvia mostly occur at higher than average rainfall values, while Echinodermata, Insecta, Ichthyoplankton, Decapoda, and Hydrozoa occur when DO values are higher. Polychaeta was associated with high Chl- $a$ values. Copepoda, Sagittoidea, and Trematoda were zooplanktonic taxonomic groups located near the center of the ordination due to their high frequency of appearance and abundance, showing minimal correlation with environmental changes.

\section{DISCUSSION}

The present study is the first contribution to understand the dynamics of the zooplankton community in the influence of the González River, the well-known spawning ground of snooks by local anglers. The zooplankton community in the area of study was vastly dominated by copepods, showing seasonal variations with significant peaks during the SSS, which is also strongly influenced by the dynamics of the river discharge. The increases in the abundance of zooplankton during the SSS are associated with the increased nutrient inputs of the González River plume, particularly during August-October. Zooplankton abundance peaks appear a few weeks after rainfall and SST increases. Zavala-García et al. (2016) reported that south of Campeche Bay, the magnitude of the zooplankton biomass depended on the continental water discharges directly related to the volume discharged into the ocean. The nutrient load is reflected by an increase of sea surface Chl- $a$ concentrations during September-November starting its descent in concentration during December. This seasonal pattern agrees 

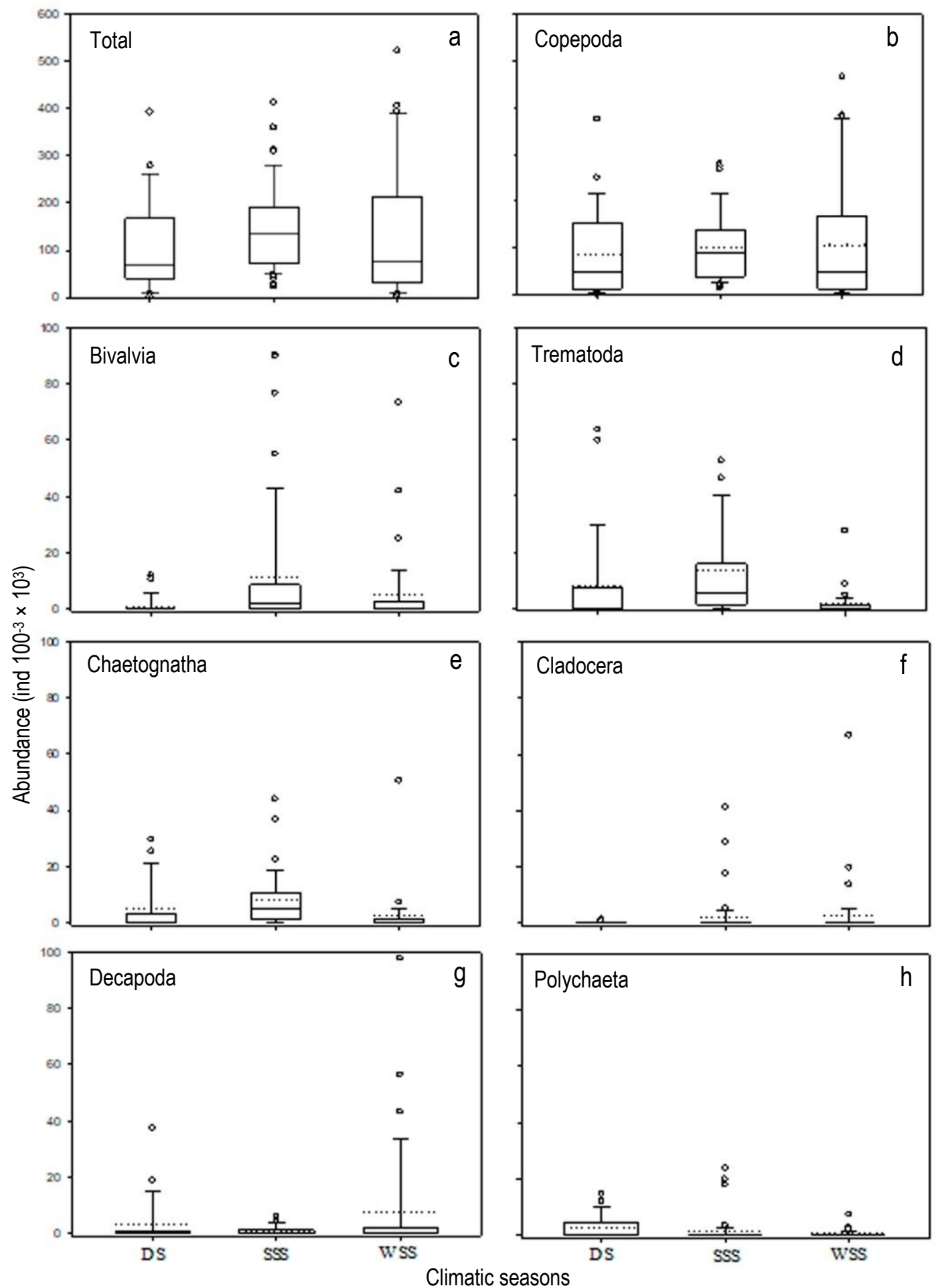

Figure 4. Seasonal average standardized abundance expressed in thousands of individuals per $100 \mathrm{~m}^{3}$. DS: dry season $(\mathrm{n}=$ 27); SSS: summer storm season $(\mathrm{n}=45)$; and WSS: winter storm season $(\mathrm{n}=36)$. Open dots indicate individual extreme cases.

with the increase of abundance and diversity of siphonophores in the southern Gulf of Mexico during October (Sanvicente-Añorve et al., 2007).
Similarly, the density of benthic macroinfauna also considerably increases during SSS in the area of influence of the Grijalva-Usumacinta River system 
Table 3. Pearson $(r)$ and Kendall (tau) correlation values from the Canonical Correspondence Analysis showing the first three axes using correlation values for each environmental variable and abundance of zooplankton taxonomic groups collected at the three zooplankton sampling stations during 2011-2012 (combined abundance of the three zooplankton mesh sizes). The larger Pearson correlation values are shown in bold. SST: sea surface temperature; Sal: salinity; DO: dissolved oxygen concentration; Rain: cumulative rainfall; sea surface Chl- $a$ : chlorophyll- $a$ concentration. Actinopterygii (includes fish eggs and larvae).

\begin{tabular}{|c|c|c|c|c|c|c|c|c|c|}
\hline \multirow{2}{*}{ Axis } & \multicolumn{3}{|c|}{1} & \multicolumn{3}{|c|}{2} & \multicolumn{3}{|c|}{3} \\
\hline & $r$ & $\mathrm{R}^{2}$ & tau & $r$ & $\mathrm{R}^{2}$ & tau & $r$ & $\mathrm{R}^{2}$ & tau \\
\hline SST & -0.532 & 0.283 & -0.394 & -0.213 & 0.046 & -0.220 & 0.548 & 0.301 & 0.408 \\
\hline Sal & -0.249 & 0.062 & -0.273 & 0.281 & 0.071 & -0.217 & 0.059 & 0.004 & 0.031 \\
\hline DO & 0.770 & 0.593 & 0.597 & -0.084 & 0.007 & -0.046 & -0.642 & 0.412 & -0.510 \\
\hline Rain & -0.854 & 0.728 & -0.625 & -0.104 & 0.011 & -0.167 & -0.229 & 0.053 & 0.008 \\
\hline Chl- $a$ & -0.290 & 0.084 & -0.122 & 0.781 & 0.610 & 0.551 & -0.099 & 0.010 & -0.095 \\
\hline Copepoda & -0.303 & 0.092 & -0.206 & 0.054 & 0.003 & 0.023 & 0.169 & 0.028 & 0.120 \\
\hline Polychaeta & 0.015 & 0.000 & 0.041 & 0.332 & 0.111 & 0.259 & 0.064 & 0.004 & 0.056 \\
\hline Euphausiacea & -0.071 & 0.005 & -0.034 & -0.058 & 0.003 & -0.025 & -0.073 & 0.005 & -0.047 \\
\hline Amphipoda & 0.127 & 0.016 & 0.115 & 0.095 & 0.009 & 0.098 & -0.122 & 0.015 & -0.098 \\
\hline Gastropoda & 0.014 & 0.000 & -0.011 & -0.209 & 0.044 & -0.177 & -0.039 & 0.001 & 0.003 \\
\hline Decapoda & 0.140 & 0.020 & 0.103 & -0.158 & 0.025 & -0.119 & 0.082 & 0.007 & 0.063 \\
\hline Echinodermata & 0.166 & 0.027 & 0.106 & -0.174 & 0.030 & -0.169 & 0.115 & 0.013 & 0.168 \\
\hline Appendicularia & -0.316 & 0.100 & -0.223 & -0.073 & 0.005 & -0.043 & 0.267 & 0.072 & 0.184 \\
\hline Hydrozoa & 0.167 & 0.028 & 0.130 & 0.037 & 0.001 & 0.049 & -0.018 & 0.000 & -0.016 \\
\hline Bivalvia & -0.463 & 0.211 & -0.297 & -0.071 & 0.005 & -0.062 & -0.198 & 0.039 & -0.127 \\
\hline Stomatopoda & -0.097 & 0.009 & -0.111 & 0.345 & 0.119 & 0.116 & 0.042 & 0.002 & 0.037 \\
\hline Sagittoidea & -0.308 & 0.098 & -0.257 & -0.183 & 0.033 & -0.192 & 0.124 & 0.015 & 0.096 \\
\hline Cladocera & -0.078 & 0.006 & -0.066 & -0.128 & 0.016 & -0.095 & -0.153 & 0.023 & -0.093 \\
\hline Trematoda & -0.310 & 0.096 & -0.258 & -0.076 & 0.006 & -0.062 & 0.234 & 0.055 & 0.176 \\
\hline Insecta & 0.065 & 0.004 & 0.042 & -0.036 & 0.001 & -0.042 & 0.146 & 0.021 & 0.127 \\
\hline Actinopterygii & 0.075 & 0.006 & 0.046 & -0.020 & 0.000 & -0.002 & 0.051 & 0.003 & 0.051 \\
\hline
\end{tabular}

(Hernández-Arana et al., 2003). The increase of zooplankton abundance during the SSS is consistent with a pattern associated with high rainfall, an increase in sea surface temperature, and a decrease in salinity (Flores-Coto et al., 2009), particularly during September and October. The first small zooplankton peak abundance observed in May, is probably related to the first rainfalls of the year, with a previous slight increase in sea surface Chl- $a$ concentration. However, during the following months of early summer, when the temperature reaches the highest values, zooplankton richness and abundance decreased considerably. Estrada et al. (2009) showed that sea surface temperature varies seasonally $\left(25-30^{\circ} \mathrm{C}\right)$ in the area of study, indicating that this situation is characteristic for the southern Gulf of Mexico. Espinosa-Fuentes et al. (2009) highlighted that zooplanktonic biomass and ichthyoplankton density were strongly influenced by temperature and the mixing processes present in the same region of the Gulf of Mexico. As mentioned above, planktonic blooms are related to the nutrient load incoming from the river discharges during heavy rainfalls.

The study area is considered a highly productive region (Zavala-García et al., 2016), presenting a close relationship between zooplankton biomass and the volume of continental water discharges. During 2011, the highest levels of rainfall occurred during September-October, considerably increasing the freshwater volume discharged by the Grijalva-Usumacinta River system. In this region, stable horizontal salinity and density gradients are induced by the inflow of the Grijalva-Usumacinta river plume (Monreal-Gómez et al., 1992; Flores-Coto et al., 2010a). The sediment load in the Grijalva-Usumacinta River system usually has the highest values in September and October, with the highest water discharges of these rivers (Muñoz-Salinas \& Castillo, 2015). The phytoplankton community assimilates the input flow of nutrients on the continental shelf, causing higher concentrations of chlorophyll- $a$ during rainfall season, promoting an increase of diversity and abundance of the herbivore 


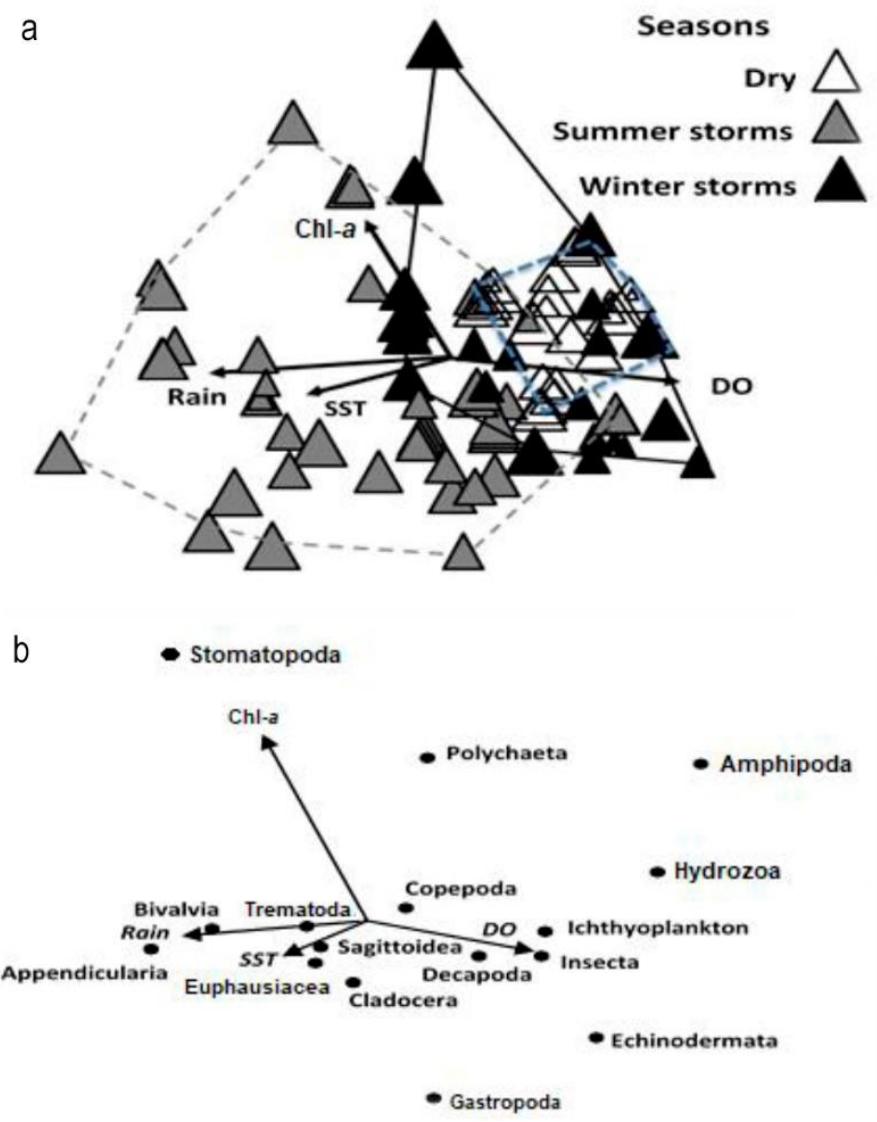

Figure 5. Biplot from the canonical correspondence analysis of zooplankton taxonomic groups collected from March 2011 to February 2012 at the southern Gulf of Mexico. a) Seasonal associations of zooplankton samples (classified per climatic seasons) as a function of the most influential environmental variables: cumulative rainfall (rain), dissolved oxygen concentration (DO), sea surface temperature (SST), and chlorophyll- $a(\mathrm{Chl}-a)$, b) same CCA showing seasonal association of the zooplankton identified per taxonomic group as a function of the same five environmental variables. Vector length indicates the magnitude of the explained variability by environmental variables. The origin $(0,0)$ is the mean of each environmental variable, transects projecting on the side opposite to the arrow are inferred to exhibit a lower-than-average variable value.

and omnivore zooplankton groups (ContrerasEspinoza, 2016). The ecological influence that nutrient discharges of rivers have on phytoplankton and zooplankton has been documented worldwide (FloresCoto et al., 2000; Cotrim da Cunha et al., 2007). The Mississippi River discharges have been well recorded to directly associate with zooplankton abundance and composition and the zooplankton's predators in the northern region of the Gulf of Mexico (Ortner et al., 1989; Lohrenz et al., 1990). High levels of zooplankton abundance have been associated with fluvial and lagoon systems in the southern part of the Gulf of Mexico while decreasing the abundance of zooplankton offshore (Ordóñez-López \& Ornelas-Roa, 2003; Contreras-Espinoza, 2016; Rowe, 2017).

The abundance of copepods drives numbers of zooplankton seasonal variability in the area of study.
Their broad distribution patterns and high abundance are mainly due to their short life cycles and fast reproduction rates (adult females can release eggs daily) (Suárez-Morales, 2000; Suárez-Morales et al., 2009; Morales-Serna \& Gómez, 2012). Copepoda is the dominant taxonomic group (both in numbers and biomass) in most coastal and open-ocean habitats of the Gulf of Mexico (Rowe, 2017) and the National Park Sistema Arrecifal Veracruzano (Okolodkov et al., 2011). Similarly, Espinosa-Fuentes et al. (2009) concluded that nauplii and copepodite stages dominated zooplanktonic biomass on the continental shelf of Campeche, Mexico.

Chaetognaths (Sagittoidea) and Bivalvia were other abundant zooplankton taxonomic groups. A direct association between Copepoda and Sagittoidea abundance has been observed because arrow worms 
mostly prey on copepods (Sato et al., 2011; Cota-Meza et al., 2015). The Gulf of Mexico contains almost 20\% of all known species of Sagittoidea (Hernández-Flores et al., 2009) with distribution patterns primarily influenced by salinity and temperature, and they may be frequent predators of fish larvae (Mille-Pagaza \& Carrillo-Laguna, 2003; Lozano-Cobo et al., 2017). High abundances of Bivalvia larvae are likely related to the natural oyster production in the coastal lagoons near the region (Zamora \& Aranda, 2000).

Appendicularia and Euphausiacea were mainly observed during the rainfall season. Euphausiacea species tend to form dense aggregations in temperate zones and cold upwelling waters, providing highly attractive biomass for plankton and nekton predators (Galtsoff, 1954; Fernández et al., 2002). The ecology of Euphausiacea has been widely investigated in the Caribbean Sea and the Gulf of Mexico, showing considerably higher abundances and lower diversity along the coastal zones than in oceanic regions (Gasca et al., 2001; Castellanos \& Gasca, 2002; Castellanos et $a l ., 2009)$. In any case, their abundance estimated in the present study did not reach the highly-dense aggregations observed in temperate zones of the Gulf of Mexico (Gasca et al., 2001; Castellanos \& Gasca, 2002). Biggs et al. (1997) showed that high levels of reproductive activity of krill (evidenced by the high abundance of early larval stages) in the southern Gulf of Mexico occur during summer. The high abundance of Appendicularia has been reported near the continental shelf of Tabasco, influenced by continental water discharge, which decreases salinity and causes low temperatures. These conditions favor food availability during the rainfall season (Flores-Coto et al., 2010a,b).

Fish eggs and larvae diversity and richness are considerably higher in coastal than in oceanic habitats (Monreal-Gómez \& Salas de León, 2004; Flores-Coto et al., 2009). Zooplankton community structure and abundance, as well as sea surface chlorophyll- $a$ concentration recorded in the present study, were spatially homogenous due to the small area investigated over the continental shelf, but with significantly distinct seasonal variability. Centropomids have been reported spawning in the Grijalva-Usumacinta River system during periods with high zooplankton availability (Hernández-Vidal et al., 2014). Copepods were noticeably dominant throughout the year in this coastal and shallow habitat, suggesting they are the most abundant and frequent prey available for fish larvae. Fish eggs and larvae collected during September and November 2011 confirmed the area of study is also an active spawning site. To understand the role that zooplankton play in the diets of fish larvae in this region, future research must investigate their feeding habits using evidence of stomach content and meta genetic methods. The results of the present study help to delimit the periods in the year with a higher abundance of each of the zooplankton taxonomic groups, and knowing the feeding habitat of fish larvae may help to detect which species of the zooplankton can be reared to feed fish larvae under laboratory conditions.

Generalizations of the seasonal fluctuations of the zooplanktonic community observed in the present annual cycle (March 2011-February 2012) should be treated with caution since the association between the measured environmental variables and the taxonomic composition of the zooplanktonic community certainly change interannually. Rowe (2017) proposed the hypothesis that the low densities and biomass of zooplankton in the southern Gulf of Mexico is caused by the limited production of phytoplankton, which is limited by the lack of inorganic nutrients, principally nitrates. The author acknowledged that there are exceptions in areas near the river's mouth at the base of the Gulf of Campeche. The effect of type and concentration of nutrients, not included in this study, must be investigated in this region to infer the mechanisms that control phytoplankton and zooplankton species assemblages in the GrijalvaUsumacinta River system.

\section{CONCLUSIONS}

Zooplankton collected off the coast of Tabasco exhibited a higher relative abundance during the DS than during dry and WSS. This pattern is probably due to increased levels of nutrients provided by rivers of the Grijalva-Usumacinta River system. These rivers favor primary productivity and foster energy transference within the regional pelagic food web. Copepoda, Bivalvia, Trematoda, and Sagittoidea were the zooplankton taxonomic groups with the highest abundance throu-ghout the year.

\section{ACKNOWLEDGMENTS}

Authors thank the anglers from the Sociedad Cooperativa de Pescadores "San Ramón" de Tabasco, especially Ramón Domínguez-Sánchez, for his invaluable logistical support during our biological and environmental surveys. This investigation was a part of the Aquaculture Collaborative Research Support Program, supported partly by the United States Agency for Internal Development (USAID) (LAG-G-00-9690015-00). The opinions expressed herein are those of 
the authors and do not necessarily reflect the AquaFish Innovation $\mathrm{Lab}$ or USAID views. CONACyT provided a Ph.D. scholarship to Leonardo Cruz-Rosado (258602). WMCS and J.G.G. are grant holders from SNI-CONACyT. J.G.G. is also a grant holder from COFAA-IPN and EDI-IPN fellowship.

\section{REFERENCES}

Álvarez-Fernández, S., Licandro P., Van Damme, C.J.G. \& Hufnagl, M. 2015. Effect of zooplankton on fish larval abundance and distribution: a long-term study on North Sea herring (Clupea harengus). ICES Journal of Marine Science, 72(9): 2569-2577. doi: 10.1093/ icesjms/fsv140

Alvariño, A. 1980. The relation between the distribution of zooplankton predators and anchovy larvae. California Cooperative Oceanic Fisheries Investigations. Reports, 21: 150-160.

Ayala-Pérez, L.A., Terán-González, G.J., FloresHernández, D., Ramos-Miranda, J. \& Sosa-López, A. 2012. Variabilidad espacial y temporal de la abundancia y diversidad de la comunidad de peces en la costa de Campeche, México. Latin American Journal of Aquatic Research, 40(1): 63-78. doi: 10.3856/ vol40-issue1-fulltext-7

Báez, P. 1997. Key to the families of decapod crustacean larvae collected off northern Chile during an El Niño event. Investigaciones Marinas, Valparaíso, 25: 167176.

Biggs, D.C., Zimmerman, R.A., Gasca, R., SuárezMorales, E., Castellanos, I. \& Leben, R.R. 1997. Note on plankton and cold-core rings in the Gulf of Mexico. Fishery Bulletin, 95(2): 369-375.

Boltovskoy, D. 1981. Atlas del zooplancton del Atlántico Sudoccidental y métodos de trabajo con el zooplancton marino. Instituto Nacional de Investigación y Desarrollo Pesquero. Publicación Especial, Mar del Plata, 937 pp.

Botello, A.V., Rendón-von Osten, J., Gold-Bouchot, G. \& Agraz-Hernández, C. 2005. Golfo de México, contaminación e impacto ambiental: diagnóstico y tendencias. Universidad Autónoma de Campeche, Universidad Nacional Autónoma de México, Instituto Nacional de Ecología, 696 pp.

Castellanos, I.A. \& Gasca, R. 2002. Eufáusidos (Crustacea: Malacostraca) del centro y sur del mar Caribe mexicano. Revista de Biología Tropical, 50(1): 77-85.

Castellanos, I., Suárez-Morales, E. \& Morales-Ramírez, Á. 2009. Euphausiids. In: Werhtmann, I. \& Cortés, J. (Eds.). Marine biodiversity of Costa Rica, Central America. Springer, Dordrecht, pp. 199-207.
Conde-Porcuna, J.M., Ramos-Rodríguez, E. \&. MoralesBaquero, R. 2004. El zooplancton como integrante de la estructura trófica de los ecosistemas lénticos. Revista Ecosistemas, 13(2): 23-29.

Contreras-Espinoza, B. 2016. Variación espacio-temporal de la estructura comunitaria del zooplancton y su relación con las variables hidrográficas en la desembocadura del Río Jamapa, Veracruz, en dos temporadas climáticas (nortes y lluvias). Tesis de Doctorado, Universidad Veracruzana, Veracruz, $90 \mathrm{pp}$.

Cota-Meza, M.S., Fernández-Álamo, M.A. \& FunesRodríguez, R. 2015. Abundancia espacio temporal de Flaccisagitta enflata y de la comunidad Chaetognatha en un ciclo circadiano en el Sistema Lagunar de Bahía Magdalena, Baja California Sur, México. Hidrobiológica, 25(3): 417-426.

Cotrim da Cunha, L., Buitenhuis, E.T., Le Quéré, C., Giraud, X. \& Ludwig, W. 2007. Potential impact of changes in river nutrient supply on global ocean biogeochemistry. Global Biogeochemical Cycles, 21(4): GB4007. doi: 10.1029/2006GB002718

Espinosa-Fuentes, M.L., Flores-Coto, C., SanvicenteAñorve, L. \& Zavala-García, F. 2009. Vertical distribution of zooplankton biomass and ichthyoplankton density during an annual cycle on the continental shelf of the southern Gulf of Mexico. Revista de Biología Marina y Oceanografía, 44(2): 477-488.

Estrada, A.E.C., Rodríguez, O.O.D., Bencomo, R.R., Amador, H.T. \& Olego, J.C. 2009. Caracterización de la temperatura superficial del mar en el Golfo de México, Mar Caribe y Atlántico cercano. Revista Cubana de Meteorología, 15(1): 45-58.

Fernández, D., Escribano, R. \& Hidalgo, P. 2002. Distribución de eufáusidos en el sistema de surgencia frente a la península de Mejillones $\left(23^{\circ} \mathrm{S}\right)$ asociada a condiciones previas y durante El Niño 1997-98. Investigaciones Marinas, Valparaíso, 30(1): 25-43.

Flores-Coto, C., Gutiérrez, R.M., González-Félix, M., Sanvicente-Añorve, L. \& García, F.Z. 2000. Annual variation of ichthyoplankton assemblages in neritic waters of the southern Gulf of Mexico. Caribbean Journal of Science, 36(3/4): 233-243.

Flores-Coto, C., Espinosa-Fuentes, M.D.L.L., ZavalaGarcía, F. \& Sanvicente-Añorve, L. 2009. Ictioplancton del sur del Golfo de México: un compendio. Hidrobiológica, 19(1): 49-76.

Flores-Coto, C., Sanvicente-Añorve, L. \& SánchezRamírez, M. 2010a. Appendicularian distribution and diversity in the southern Gulf of Mexico. Revista Mexicana de Biodiversidad, 81(1): 123-131.

Flores-Coto, C., Sanvicente-Añorve., L. VázquezGutiérrez, F. \& Sánchez-Ramírez, M. 2010b. Mesoscale distribution of Oikopleura and Fritillaria (Appen- 
dicularia) in the southern Gulf of Mexico: spatial segregation. Revista de Biología Marina y Oceanografía, 45(3): 379-388.

Galtsoff, P.S. 1954. Gulf of Mexico, its origins, waters, and marine life. Fishery Bulletin, 89(55): 1-604.

Gasca, R., Castellanos-Osorio, I.A. \& Biggs, D.C. 2001. Euphausiids (Crustacea, Euphausiacea) and summer mesoscale features in the Gulf of Mexico. Bulletin of Marine Sciences, 68(3): 397-408.

Hernández-Arana, H.A., Rowden, A.A., Attrill, M.J., Warwick, R.M. \& Gold-Bouchot, G. 2003. Largescale environmental influences on the benthic macroinfauna of the southern Gulf of Mexico. Estuarine, Coastal and Shelf Science, 58(4): 825-841.

Hernández-Flores, R.M., McLelland, J.A. \& SuárezMorales, E. 2009. Planktonic Chaetognatha of the Gulf of Mexico. In: Felder, D.L. \& Camp, D.K. (Eds.). Gulf of Mexico origins, waters, and biota. Volume I biodiversity. Texas A\&M Press, Texas, pp. 1165-1171.

Hernández-Vidal, U., Chiappa-Carrara, X. \& ContrerasSánchez, W.M. 2014. Reproductive variability of the common snook, Centropomus undecimalis, in environments of contrasting salinities interconnected by the Grijalva-Usumacinta fluvial system. Ciencias Marinas, 40(3): 173-185. doi: 10.7773/cm.v40i3.2381

Herrera-Silveira, J.A., Lara-Domínguez, A.L., Day, J.W., Yáñez-Arancibia, A., Ojeda, S.M., Hernández, C.T. \& Kemp, G.P. 2019. Ecosystem functioning and sustainable management in coastal systems with high freshwater input in the southern Gulf of Mexico and Yucatan Peninsula. In: Wolansky, E., Day, J.W., Elliot, M. \& Ramachandran, R. (Eds.). Coasts and estuaries: the future. Elsevier, Amsterdam, pp. 377397. doi: 10.1016/b978-0-12-814003-1.00022-8

Hopkins, T.L. 1982. The vertical distribution of zooplankton in the eastern Gulf of México. Deep-Sea Oceanographic Research Papers, 29(9): 1069-1083. doi: 10.1016/0198-0149(82)90028-0

Jackson, J.M. \& Lenz, P.H. 2016. Predator-prey interactions in the plankton: larval fish feeding on evasive copepods. Scientific Reports, 6(33585): 1-11. doi: 10.1038/srep33585

Lohrenz, S.E., Dagg, M.J. \& Whitledge, T.E. 1990. Enhanced primary production at the plume/oceanic interface of the Mississippi River. Continental Shelf Research, 10(7): 639-664. doi:10.1016/0278-4343(90) 90043-L

Lozano-Cobo, H., Del Prado, M.D.C.G., SánchezVelasco, L. \& Gómez-Gutiérrez, J. 2017. Seasonal variation in chaetognath and parasite species assemblages along the northeastern coast of the Yucatan Peninsula. Diseases of Aquatic Organisms, 124(1): 5575. doi: $10.3354 /$ dao03106
McCune, B. \& Mefford, M.J. 2011. PC-ORD: Multivariate analysis of ecological data. Version $6.0 \mathrm{MjM}$ Software. Gleneden Beach, Oregon, USA.

Mille-Pagaza, S. \& Carrillo-Laguna, J. 2003. Distribución y abundancia de los quetognatos de la plataforma Tamaulipeca y océano adyacente en abril de 1987. Hidrobiológica, 13(3): 223-229.

Monreal-Gómez, M.A. \& Salas de León, D.A. 2004. Golfo de México, circulación y productividad. Ciencias, 76: 24-33.

Monreal-Gómez, M.A., Salas de León, D.A., PadillaPilotze, A.R. \& Alatorre-Mendieta, M.A. 1992. Hidrografía y estimación de corrientes de densidad en el sur de la Bahía de Campeche, México. Ciencias Marinas, 18: 115-133.

Morales-Serna, F.N. \& Gómez, S. 2012. Generalidades de los copépodos parásitos de peces en aguas profundas y el caso de Lophoura brevicollum (Siphonostomatoida: Sphyriidae). In: Zamorano, P., Hendrickx, M.E. \& Caso, M. (Eds.). Biodiversidad y comunidades del talud continental del Pacífico mexicano. Secretaría de Medio Ambiente y Recursos Naturales, Instituto Nacional de Ecología, Ciudad de México, pp. 145-158.

Muñoz-Salinas, E. \& Castillo, M. 2015. Streamflow and sediment load assessment from 1950 to 2006 in the Usumacinta and Grijalva Rivers (Southern Mexico) and the influence of ENSO. Catena, 127: 270-278. doi: 10.1016/j.catena.2015.01.007

Okolodkov, Y.B., Aké-Castillo, J.A., Gutiérrez-Quevedo, M.G., Pérez-España, H. \& Salas-Monreal, D. 2011. Annual cycle of the plankton biomass in the National Park Sistema Arrecifal Veracruzano, southwestern Gulf of Mexico. In: Kattel, G. (Ed.). Zooplankton and phytoplankton: types, characteristics and ecology. Nova Science Publishers, New York, pp. 63-88.

Ordóñez-López, U. \& Ornelas-Roa, M. 2003. Variaciones de la comunidad de copépodos plánticos en el gradiente estuarino-costero de Celestún, Yucatán, México. Hidrobiológica, 13(3): 231-238.

Ortner, P.B., Hill, L.C. \& Cummings, S.R. 1989. Zooplankton community structure and copepod species composition in the northern Gulf of Mexico. Continental Shelf Research, 9(4): 387-402.

Perry, R.A. 2003. A guide to the common inshore marine plankton of southern Californian. Malibu High School \& UCLA Ocean Globe, Los Angeles.

Phelps, R.P., Sumiarsa, G.S., Lipman, E.E., Lan, H.P., Moss, K.K. \& Davis, A.D. 2005. Intensive and extensive production techniques to provide copepod nauplii for feeding larval red snapper Lutjanus campechanus. In: Lee, C.-S., O'Bryen, P.J. \& Marcus, N.H. (Eds.). Copepods in aquaculture. Blackwell Publishing, Oxford, pp. 151-168. 
Puello-Cruz, A.C., González-Rodríguez, B. \& GarcíaOrtega, A. 2008. Investigación en producción y uso de copépodos en larvicultura marina. Avances en Nutrición Acuícola. IX Simposio Internacional de Nutrición Acuícola, Ensenada, pp. 24-27.

Purcell, J.E. \& Grover, J.J. 1990. Predation and food limitation as causes of mortality in larval herring at a spawning ground in British Columbia. Marine Ecology Progress Series, 59: 55-61. doi: 10.3354/ meps059055

Rowe, G.T. 2017. Offshore plankton and benthos of the Gulf of Mexico. In: Rowe, G.T. (Ed.). Habitats and biota of the Gulf of Mexico: before the deepwater horizon oil spill. Springer, New York, pp. 641-767.

Sanvicente-Añorve, L., Alba, C., Alatorre, M.A. \& FloresCoto, C. 2007. Cross-shelf and vertical distribution of siphonophore assemblages under the influence of freshwater outflows in the southern Gulf of Mexico. Hydrobiologia, 586(1): 69-78.

Sato, N.E., Hernández, D. \& Viñas, M.D. 2011. Hábitos alimentarios de Sagitta friderici Ritter-Záhony en las aguas costeras de la provincia de Buenos Aires, Argentina. Boletín de Investigaciones Marinas y Costeras, 40(1): 59-74.

Sherman, K., Smith, W., Morse, W., Berman, M., Green, J. \& Ejsymont, L. 1984. Spawning strategies of fishes in relation to circulation, phytoplankton production, and pulses in zooplankton off the northeastern United States. Marine Ecology Progress Series, 18(1): 1-19.

Smith, D.G. 1977. A guide to marine coastal plankton and marine invertebrate larvae. Kendall/Hunt Publishing Company, Iowa.

Støttrup, J.G. 2006. A review on the status and progress in rearing copepods for marine larviculture. Advantages and disadvantages among calanoid, harpacticoid and cyclopoid copepods. In: Cruz-Suárez, L.E., Ricque, D.M., Tapia-Salazar, M., Nieto-López, M.G., Villarreal-Cavazos, D.A., Puello-Cruz, A.C. \& García-Ortega, A. (Eds.). Avances en Nutrición Acuícola. VIII Simposium Internacional de Nutrición Acuícola. 15-17. Universidad Autónoma de Nuevo León, Monterrey, Nuevo León.

Received: January 21, 2020; Accepted: April 8, 2020
Suárez-Morales, E. 2000. Copépodos, seres ubicuos y poco conocidos. CONABIO. Biodiversitas, 29: 7-11.

Suárez-Morales, E., Fleeger, J.M. \& Montagna, P.A. 2009. Free-living Copepoda of the Gulf of Mexico. In: Felder, D.L. \& Camp, D.K. (Eds.). Gulf of Mexico origins, waters, and biota. Volume I Biodiversity. Texas A\&M University Press, Texas, pp. 41-870.

Ter Braak, C.J.F. \& Verdonschot, P.F.M. 1995. Canonical correspondence analysis and related multivariate methods in aquatic ecology. Aquatic Sciences, 57(3): 255-289. doi: 10.1007/bf00877430

West, R.C., Psuty, N.P. \& Thom, B.G. 1985. Las tierras bajas de Tabasco. Gobierno del Estado de Tabasco, Biblioteca Básica Tabasqueña, Tabasco.

World Register of Marine Species (WoRMS). 2019. World Register of Marine Species [http://www.marinespecies.org/]. Reviewed: December 9, 2019.

Yáñez-Arancibia, A. \& Day, J.W. 2004. Environmental sub-regions in the Gulf of Mexico coastal zone: the ecosystem approach as an integrated management tool. Ocean \& Coastal Management, 47(11-12): 727-757.

Yúfera, M. \& Darias, M.J. 2007. The onset of exogenous feeding in marine fish larvae. Aquaculture, 268(1-4): 53-63.

Zamora, A.G. \&. Aranda, D.A. 2000. Producción somática de dos especies de Crassostrea virginica e Ischadium recurvum (Bivalvia) en Mecoacán, Tabasco, México. Revista de Biología Tropical, 48(1): 65-75.

Zavala-García, F., Flores-Coto, C. \& Espinosa-Fuentes, M, de la L. 2016. Relationship between zooplankton biomass and continental water discharges in the southern Gulf of Mexico (1984-2001). Revista de Biología Marina y Oceanografía, 51(1): 21-31. 